\title{
$17 \alpha$-Hydroxylase deficiency with persistence of Mullerian ducts in a genotypic male and paradoxical aldosterone
} secretion

\author{
N.S. Panesar, V.T.F. Yeung ${ }^{1}$, J.C.N. Chan ${ }^{2}$, C.C. Shek, M.G. Nicholls ${ }^{3}$ and \\ C.S. Cockram ${ }^{1}$
}

\begin{abstract}
Departments of Chemical Pathology, ${ }^{1}$ Medicine and ${ }^{2}$ Clinical Pharmacology, The Chinese University of Hong Kong, Shatin, N.T., Hong Kong and ${ }^{3}$ Department of Medicine, The Christchurch School of Medicine, University of Otago, Christchurch, New Zealand
\end{abstract}

\begin{abstract}
Summary: We report a case of congenital adrenal hyperplasia due to $17 \alpha$-hydroxylase deficiency in a Chinese genotypic male patient. Despite the male genotype, normal female external genitalia were present and with the introduction of cyclical oestrogen therapy withdrawal bleeding occurred, confirming the presence of functional endometrial tissue. We believe this to be the first report of persistent Mullerian duct structures in a genotypic male with 17 $\alpha$-hydroxylase deficiency. It could be explained by either impaired secretion or impaired action of anti-Mullerian hormone. Further, contrary to the usual finding of suppressed aldosterone secretion, this patient had measurable levels of plasma aldosterone.
\end{abstract}

\section{Introduction}

$17 \alpha$-Hydroxylase deficiency causing congenital adrenal hyperplasia is a rare disorder which was first recognized in 1966; only about 120 cases have been reported so far. ${ }^{1,2}$ The enzyme deficiency is present in the adrenals and gonads and affects both sexes. Deficiency of $17 \alpha$-hydroxylase causes diminished secretion of glucocorticoids and sex hormones and excess production of 17-deoxycorticosteroids, especially deoxycorticosterone (DOC) and corticosterone. ${ }^{1}$ Affected patients usually present with hypertension and hypokalaemia due to excess DOC secretion. Excessive DOC causes retention of sodium and with ensuing blood volume expansion, the renin-angiotensin system is suppressed, which in turn leads to diminished secretion of aldosterone by the zona glomerulosa. ${ }^{2}$ However, the concentration of 18-hydroxycorticosterone which is the immediate precursor of aldosterone has been reported to be elevated. ${ }^{3}$ More recently it has been reported that circulating aldosterone concentrations may be normal or elevated. ${ }^{4}$

The lack of sex hormones causes sexual infantilism in untreated females and pseudohermaphroditism in males. ${ }^{5}$ Secondary sexual characteristics

Correspondence: C.S. Cockram, B.Sc., M.D., F.R.C.P., F.R.C.P.E.

Reprints requests to: N.S. Panesar.

Accepted: 14 August 1992 in males may range from apparently normal female genitalia and a blind vaginal pouch to hypospadias and a small phallus. ${ }^{6-8}$ In the few reported cases of male pseudohermaphrodites, persistence of Mullerian ducts has not been described. ${ }^{6-8}$

We report the occurrence of $17 \alpha$-hydroxylase deficiency in a Chinese patient with a male genotype. The unusual finding was the persistence of Mullerian duct structures.

\section{Materials and methods}

Aldosterone, cortisol, 17 $\beta$-oestradiol, progesterone, $17 \alpha$-hydroxyprogesterone, testosterone, luteinizing hormone (LH) and follicle stimulating hormone (FSH) were assayed using commercial immunoassay kits obtained from Diagnostic Products Corporation (USA). Plasma renin activity (PRA) was assayed using a kit from Serono Diagnostic S.A. (Switzerland). ACTH was assayed using an Allergo HS.ACTH radioimmunometric assay kit from Nichols Institute (USA). The intraand inter-assay precisions for all of the assays were less than $15 \%$.

Corticosterone, deoxycorticosterone, and 18hydroxycorticosterone were assayed by Dr Robert Fraser, MRC Blood Pressure Unit, Western Infirmary, Glasgow, Scotland. Dr Fraser also assisted with the additional assay of aldosterone using radioimmunoassay after prior chromatographic separation. 


\section{Case report}

A phenotypic female, then aged 17 , was admitted to hospital in 1988 for screening, her elder sister having been diagnosed as having $17 \alpha$-hydroxylase deficiency following investigation for primary amenorrhoea.

When contacted for screening a history of primary amenorrhoea was obtained. On admission the patient was noted to have an eunuchoidal build. Her height was $163.5 \mathrm{~cm}$ and weight $46.5 \mathrm{~kg}$. She had normal, although infantile, female external genitalia and no gonadal tissue could be palpated in the inguinal region. Severe hypertension (blood pressure $250 / 150 \mathrm{mmHg}$ ) and hypokalaemic alkalosis (plasma $\mathrm{K}^{+} 2.1 \mathrm{mmol} / 1$, plasma $\mathrm{HCO}_{3}{ }^{-}$ $33 \mathrm{mmol} / \mathrm{l})$ were documented. The clinical diagnosis of $17 \alpha$-hydroxylase deficiency was confirmed by the finding of undetectable circulating concentrations of cortisol and $17 \alpha$-hydroxyprogesterone together with elevated concentrations of progesterone, $\mathrm{LH}$ and FSH as summarized in Table I. The aldosterone concentration was also elevated (Table I).

Chromosomal analysis performed on two separate samples on two occasions, revealed a 46 $\mathrm{XY}$ karyotype confirming that the patient has a male genotype. Ultrasonography of the pelvis demonstrated the presence of an infantile uterus and vagina. Following treatment with dexamethasone $(0.25 \mathrm{mg}$ in the morning, $0.5 \mathrm{mg}$ at night) and cyclical oestrogen therapy, blood pressure and plasma $\mathrm{K}^{+}$returned to normal and the progesterone concentration fell to $2.4 \mathrm{nmol} / \mathrm{l}$.
Although the aldosterone concentration fell to $58 \mathrm{pmol} / 1$, the PRA initially remained undetec- $\frac{\nearrow}{\square}$ table. Withdrawal bleeding occurred following $\propto$ oestrogen therapy, confirming the presence of $\leftarrow$ functional endometrial tissue. Permission for fur- $\overrightarrow{\vec{F}}$ ther investigation aimed at locating and identifying $\frac{?}{0}$ the gonads has, to date, been refused although $\frac{}{0}$ ultrasonography suggested the possible presence of $\frac{\bar{m}}{\bar{m}}$ gonadal tissue within the pelvis.

In view of the paradoxical aldosterone result she $\cong$ was reinvestigated after 1 year, informed consent $\tilde{}$ having been obtained. Whilst still on treatment the $\vec{O}$ following results were obtained: progesterone $\overrightarrow{-}$ $3.0 \mathrm{nmol} / 1, \quad 17 \alpha$-hydroxyprogesterone less than $\vec{\sigma}$ $0.3 \mathrm{nmol} / 1$, cortisol less than $28 \mathrm{nmol} / 1$, PRA in supine position $0.14 \mathrm{ng} / \mathrm{ml} /$ hour and the corresponding aldosterone $165 \mathrm{pmol} / \mathrm{l}$. ACTH was undetectable.

To stimulate the renin-angiotension-aldos- ${ }^{\circ}$ terone axis, dexamethasone treatment was then withdrawn for 1 week and a low sodium $(10 \mathrm{mmol} / \mathrm{f}$ day) and high potassium (100 mmol/day) diet 0

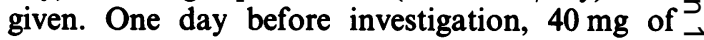
frusemide was given orally. The following morning Th blood was taken in the supine position and at 30,60 을 and 120 minutes after adopting the upright posture. The plasma ACTH had risen to $71 \mathrm{pg} / \mathrm{ml}$ and cortisol remained less than $28 \mathrm{nmol} / \mathrm{l}$. In the supinge $\overrightarrow{0}$

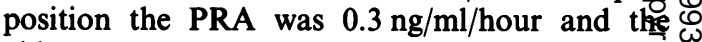
aldosterone was $533 \mathrm{pmol} / \mathrm{l}$. The PRA after 30, and 120 minutes in the upright position were 2.35 , 4.11 and $5.14 \mathrm{ng} / \mathrm{ml} /$ hour, respectively. The respective aldosterone concentrations were 519,743 and $718 \mathrm{pmol} / \mathrm{l}$. The five aldosterone specimens ob-

Table I Concentrations of hormones at presentation and after treatment with dexamethasone

\begin{tabular}{|c|c|c|c|}
\hline $\begin{array}{l}\text { Hormone } \\
\text { (reference range) }\end{array}$ & $\underset{\text { treatment }}{\text { Off }}$ & $\begin{array}{c}\text { On } \\
\text { treatment } \\
3 \text { months }\end{array}$ & $\begin{array}{c}\text { On } \\
\text { treatment } \\
\text { one year }\end{array}$ \\
\hline $\begin{array}{l}\text { Cortisol } \\
\text { (morning } 138-690 \mathrm{nmol} / \mathrm{l} \text { ) }\end{array}$ & $<28$ & - & - \\
\hline Corticosterone $(2.3-23.0 \mathrm{nmol} / \mathrm{l})$ & 71.4 & - & - \\
\hline DOC $(0.12-0.49 \mathrm{nmol} / \mathrm{l})$ & 7.0 & - & - \\
\hline $\begin{array}{l}\text { 18-Hydroxycorticosterone } \\
(0.083-0.69 \mathrm{nmol} / \mathrm{l})\end{array}$ & 8.54 & - & - \\
\hline 17 $\beta$-Oestradiol $(183-807 \mathrm{pmol} / \mathrm{l})$ & $<40$ & - & $<40$ \\
\hline Progesterone $(0-1.27 \mathrm{nmol} / \mathrm{l})$ & 27 & - & 3.0 \\
\hline $17 \alpha$-Hydroxyprogesterone $(0.3-14.4 \mathrm{nmol} / \mathrm{l})$ & $<0.3$ & 2.4 & 2.2 \\
\hline ACTH $(9-52 \mathrm{pg} / \mathrm{ml})$ & - & $<0.3$ & UD \\
\hline FSH $(0-20 \mathrm{IU} / \mathrm{l})$ & 89 & - & - \\
\hline LH $(0-38$ IU/1) & 49 & - & - \\
\hline $\begin{array}{l}\text { Aldosterone: } \\
\text { (supine: } 28-445 \mathrm{pmol} / \mathrm{l} \text { ) }\end{array}$ & 793 & $\overline{58}$ & 165 \\
\hline $\begin{array}{l}\text { PRA: } \\
\text { (supine: } 0.12-1.59 \mathrm{ng} / \mathrm{ml} / \text { hour) }\end{array}$ & $<0.07$ & $<0.07$ & 0.14 \\
\hline
\end{tabular}

$-=$ not assayed UD $=$ undetectable. 
tained during this investigation were also assayed by a chromatographic method in Dr Fraser's Laboratory (normal range: $<500 \mathrm{pmol} / \mathrm{l}$ ), and the results obtained were lower than with the direct assay (DPC coat-a-count). The results (pmol/l) were as follows (DPC $v s$ chromatographic assay): (1) 165 vs 56; (2) 533 vs 111 ; (3) 519 vs 167; (4) 743 vs 305; and (5) 718 vs 250.

\section{Discussion}

To our knowledge this is the first report of persistent Mullerian structures in a genotypic male pseudohermaphrodite with $17 \alpha$-hydroxylase deficiency. Anti-Mullerian hormone (AMH) produced by fetal Sertoli cells, ${ }^{9}$ a glycoprotein with a molecular weight of approximately $140 \mathrm{kDa}$, is responsible for the suppression of Mullerian duct development in normal males. Impairment of fetal testosterone production because of $17 \alpha$-hydroxylase deficiency, results in failed masculinization and a phenotypic female habitus. However, Mullerian structures are usually absent, presumably due to normal testicular production of AMH. Josso et $a l .{ }^{10}$ reported that testicular dysgenesis could result in deficient production of testosterone from Leydig cells along with AMH from Sertoli cells, and in the persistent Mullerian duct syndrome there could be failure of production, synthesis of an inactive form or impaired peripheral action of AMH ${ }^{10,11}$ Hutson $^{12}$ described a 12 year old girl with $17 \alpha$ hydroxylase deficiency with normal female genitalia and testes inside inguinal herniae, however there was no mention of persistent Mullerian structures. Whilst de Gennes et al. ${ }^{13}$ reported the presence of bilateral streak gonads and impaired development of Mullerian duct derivatives in a girl with $46 \mathrm{XX}$ genotype and 17 $\alpha$-hydroxylase deficiency, a causal link could not be established between the abnormalities. Whether there was coexisting deficiency of, or resistance to, AMH in our patient can only be left to conjecture. Taken together, however, it is tempting to speculate that $17 \alpha$-hydroxylase deficiency might in some way interfere with the development and hormone secretion of fetal gonads, resulting in the association of these rare disorders in the same patient.

Hutson ${ }^{12,14}$ has proposed a two-stage control of testicular descent: an abdominal stage which is controlled by a non-androgenic hormone, namely $\mathrm{AMH}$ and an inguinal stage which is androgen dependent. Scott ${ }^{15}$ also concluded that AMH rather than androgens may be responsible for the abdominal phase of testicular descent. From the aforementioned studies, one might expect to find the testes in the abdomen in our patient. However, all further imaging investigations were resolutely refused.
Aldosterone production is usually suppressed; presumably as a consequence of reduced activity of the renin-angiotensin system, hypokalaemia, chronic elevation of ACTH levels and high circulating levels of atrial natriuretic factor. However, in our patient aldosterone was detected by the direct aldosterone radioimmunoassay, the value being in the upper part of the normal range despite suppressed renin values. Other studies have also reported elevated concentrations of aldosterone. ${ }^{4,16}$ The aldosterone results could be explained by cross-reaction with other steroids. ${ }^{16}$ A comparison of the results obtained with the direct aldosterone assay (DPC coat-a-count) and by the method incorporating a chromatographic purification partially support this conclusion. While on treatment cross-reactivity accounted for a difference of approximately $100 \mathrm{pmol} / \mathrm{l}$, but the disparity increased to about $400 \mathrm{pmol} / 1$ off treatment, presumably as a result of enhanced production of other steroids with ACTH stimulation. Measurable aldosterone was, however, still present even with chromatographic separation. This, in the untreated stage, could be due to enhanced corticosterone methyloxidase type II activity and hence aldosterone production by the zona fasciculata, as has been reported in Japanese patients. ${ }^{4}$

With glucocorticoid replacement therapy the aldosterone concentrations decreased whilst PRA and potassium levels rose. Kater et al ${ }^{17}$ found that aldosterone concentrations rose following treatment for 1 week or longer during which time blood pressure, sodium, potassium, DOC and corticosterone concentrations were normalized. It is possible that aldosterone along with 18-hydroxycorticosterone is secreted from the zona fasciculata under the influence of ACTH and that suppression of ACTH by dexamethasone leads initially to a rapid drop in aldosterone. This statement is also supported by the fact that the zona glomerulosa is refractory to the action of renin after prolonged suppression. ${ }^{18}$ Consistent with this, the patient's sister had markedly raised PRA $(6.31 \mathrm{ng} / \mathrm{ml} /$ hour $)$ but suppressed aldosterone $(42 \mathrm{pmol} / \mathrm{l})$ after 3 months' dexamethasone treatment.

Also noteworthy is the fact that when the patient was taken off treatment and given a low salt diet and diuretic, PRA increased appreciably and the erect aldosterone as measured by chromatographic techniques showed a three-fold rise compared to the supine value $(305 \mathrm{pmol} / \mathrm{l}$ vs $111 \mathrm{pmol} / \mathrm{l})$. This, albeit subnormal, response to renin-angtiotensin stimulation is in accordance with Scaroni's ${ }^{19}$ findings of a transient increase of aldosterone following glucocorticoid withdrawal and prolonged recovery of aldosterone levels during longterm treatment in these patients.

In summary, a Chinese genotypic male patient with $17 \alpha$-hydroxylase deficiency has been des- 
cribed. Mullerian duct structures are retained, as confirmed with ultrasonography and occurrence of withdrawal bleeding following oestrogens. In contrast to most patients, aldosterone was detectable at presentation, and was, at least temporarily, suppressed with institution of glucocorticoid therapy.

\section{Acknowledgements}

We are indebted to Dr Robert Fraser, for performing assays of various hormones, to technical staff in the

\section{References}

1. Biglieri, E.G., Herron, M.A. \& Brust, N. 17-Hydroxylation deficiency in man. J Clin Invest 1966, 45: 1946-1954.

2. Yanase, T., Simpson, E.R. \& Waterman, M.R. 17 1 Hydroxylase/17,20-lyase deficiency: from clinical investigation to molecular definition. Endocr Rev 1991, 12: 91-108.

3. Fraser, R. \& Lantos, C.P. 18-Hydroxycorticosterone, a review. J Steroid Biochem 1978, 9: 273-286.

4. Yamakita, N., Murase, H., Yasuda, K. et al. Possible hyperaldosteronism and discrepancy in enzyme activity deficiency in adrenal and gonadal glands in Japanese patients with 17 $\alpha$-hydroxylase deficiency. Endocrinol Jap (Tokyo) 1989, 36: 515-536.

5. New, M.I. Male pseudohermaphroditism due to $17 \alpha$ hydroxylase deficiency. J Clin Invest 1970, 43: 1930-1941.

6. Kershnar, A.K., Borut, D., Kogut, M.D., Biglieri, E.G. \& Schambelan, M. Studies in a phenotypic female with $17 \alpha-$ hydroxylase deficiency. J Pediatr 1976, 89: 395-400.

7. Bricaire, H., Luton, J.P., Laudat, P. et al. A new male pseudohermaphroditism associated with hypertension due to a block fo 17a-hydroxylation. J Clin Endocrinol Metab 1972 , 35: 67-72.

8. Tourniaire, J., Audi-Parera, L., Loras, B., Blum, J., Castelnova, P. \& Forest, M.G. Male pseudohermaphroditism with hypertension due to a $17 \alpha$-hydroxylation deficiency. Clin Endocrinol 1976, 5: 53-61.

9. Tran, D. \& Josso, N. Localisation of anti-Mullerian hormone in the rough endoplasmic reticulum of the developing bovine Sertoli cell using immunocytochemistry with monoclonal antibody. Endocrinology 1982, 111: 1562-1567.

10. Josso, N., Fekete, C., Cachin, O., Nezelof, C. \& Rappaport, R. Persistence of Mullerian ducts in male pseudohermaphroditism and its relationship to cryptorchidism. Clin Endocrinol 1983, 19: $247-258$.
Immunoassay Laboratory, Department of Chemical Pathology, to Ms Begonia Yuen and Ms Hidy Yeung for typing the manuscript.

\section{Note added in proof}

A similar case to the above was published in the Postgraduate Medical Journal last year: Malcolm, P.N., Wright, D.J. \& Edmonds, C.J. Deficiency of $17 \alpha-$ hydroxylase associated with absence gonads. Postgrad Med J 1992, 68, 59-61.

11. Mouli, K., McCarthy, P., Ray, P., Ray, V. \& Rosenthal, I.M. Persistent Mullerian duct syndrome in a man with transverse testicular ectopia. J Urol 1988, 139: 373-375.

12. Hutson, J.M. Testicular feminization: a model for testicular $\overrightarrow{0}$ descent in mice and men. $J$ Pediatr Surg 1986, 21: 195-198.

13. de Gennes, J.L., Jambart, S., Turpin, G., Elkik, F. \& Roger, 음 M. 17 $\alpha$-Hydroxylase deficiency syndrome associated with bilateral streak gonads and impaired development of $\overrightarrow{ }$ Mullerian ducts derivatives. Acta Endocrinol (Copen) 1982, 100: $68-76$

14. Hutson, J.M. A biphasic model for the hormonal control of testicular descent. Lancet 1985, ii: 419-421.

15. Scott, J.E.S. The Hutson hypothesis: a clinical study. $\mathrm{Br} O$ Urol 1989, 60: 74-76.

16. Monno, K. \& Takasu, N. A new variant of $17 \alpha$-hydroxylass. deficiency with hyperaldosteronism in two Japanese sistefs Endocrinol Jap (Tokyo) 1989, 35: 315-323.

17. Kater, C.E., Biglieri, E.G., Brust, N., Chang, B. \& Hirari, J. The unique patterns of plasma aldosterone and 18 hydroxycorticosterone concentrations in the $17 \alpha$-hydroxylase deficiency syndrome. J Clin Endocrinol Metab 1982, 55: 95-302.

18. Biglieri, E.G., Slaton, P.E., Jr, Silen, W.S., Galante, M. \& Forsham, P.H. Postoperative studies of adrenal function in primary aldosteronism. J Clin Endocrinol 1966, 26: 553-558.

19. Scaroni, C., Opocher, G. \& Mantero, F. Reninangiotensin-aldosterone system: a long-term follow-up study in 17 $\alpha$-hydroxylase deficiency syndrome (170HDS). Clin Exp Hypertens [A], Theory Pract (NY) 1986, A8 (4\&5): 773-780. 